\section{International Journal of Medical Research and Review}

\title{
Serum calcium and magnesium levels in acute gastroenteritis
}

\author{
Kumar Patel N. ${ }^{\mathbf{1}}$, Kumar Kedia M. ${ }^{2}$, Majhi C. ${ }^{3}$, Kumar Bariha P. ${ }^{4}$, Oram G. ${ }^{5 *}$ \\ DOI: https://doi.org/10.17511/ijmrr.2020.i06.07
}

\footnotetext{
1 Nayan Kumar Patel, Assistant Professor, Department of Cardiology, Veer Surendra Sai Institute Of Medical Sciences And Research, Burla, Odisha, India.

2 Madhav Kumar Kedia, Senior Resident, ${ }^{\mathbf{3}}$ Chakradhar Majhi, Associate Professor, ${ }^{4}$ Prafulla Kumar Bariha, Assistant Professor, ${ }^{\mathbf{5}}$ Gouri Oram, Assistant Professor; all authors are affiliated with Department of General Medicine, Veer Surendra Sai Institute Of Medical Sciences And Research, Burla, Odisha, India.
}

Background: Acute diarrhea endemic in India has a prevalence of $7 \%$ which is commonly seen in children and also is a major problem in adults. Acute diarrhea with dehydration culminates in the loss of electrolytes. Not only $\mathrm{Na}^{+} \mathrm{K}^{+}$but also $\mathrm{Ca}^{2+}$ and $\mathrm{Mg}^{2+}$ are also substantially lost and lead to symptoms and adds to morbidity and prolong hospitalization. Methods: In this observational study, a total of 100 cases of acute gastroenteritis admitted to the department of general medicine and infectious disease ward of VIMSAR, Burla, between November 2018 to December 2019 were investigated clinically and biochemically and data were interpreted statistically. Results: Males (56\%) were more in number than females (44\%), were mostly in the age group of 26-35 years (24\%). Hypocalcemia, hypokalemia, hypomagnesemia, and hyponatremia were found in $97 \%$, 59\%, $49 \%, 48 \%$ of cases respectively. Correlation of Serum $\mathrm{Ca}^{2+}$ with ( $r$-value) total episodes of vomiting $(-0.536)$, total episode of stools $(-0.880), \mathrm{S}$. $\mathrm{Na}^{+}$level $(-0.374), \mathrm{S} . \mathrm{K}^{+}$level $(-0.729)$, with the duration of hospital stay $(-0.770)$ respectively. Correlation of $\mathrm{S}$. $\mathrm{Mg}^{2+}$ levels with ( $\mathrm{r}$-value) total episodes of vomiting $(-0.475)$, total episode of stools $(-0.498), \mathrm{S}$. $\mathrm{Na}^{+}$level $(-0.301), \mathrm{S}^{+} \mathrm{K}^{+}$level $(-0.801)$, duration of hospital stay $(-0.699)$ respectively. The correlations were found to be statistically highly significant (with a $\mathrm{p}$-value is <0.01). Conclusion: Early detection and prompt correction of electrolytes will be beneficial, as it will decrease the duration of hospital stay, morbidity, mortality, thereby, decrease the burden on the health system of the country.

Keywords: Acute Gastroenteritis, Correlation, S. Calcium, S. Magnesium

Corresponding Author

Gouri Oram, Assistant Professor, Department of General Medicine, Veer Surendra Sai Institute Of Medical Sciences And Research, Burla, Odisha, India. Email: gouri.oram@gmail.com
How to Cite this Article

Patel NK, Kedia MK, Majhi C, Bariha PK, Oram G. Serum calcium and magnesium levels in acute gastroenteritis. Int J Med Res Rev. 2020;8(6):416423.

Available From

https://ijmrr.medresearch.in/index.php/ijmrr/article/ view/1224
To Browse

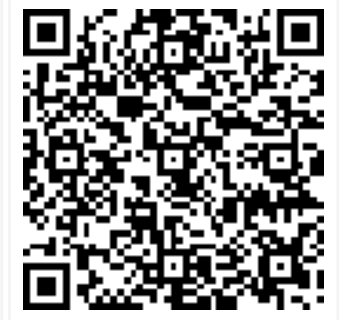

Manuscript Received 2020-11-12

Conflict of Interest No
Review Round 1 2020-11-22

Funding Nil
Review Round 2 2020-12-02

Ethical Approval Yes
Review Round 3

Accepted 2020-12-24

Plagiarism X-checker $6 \%$

Note

(c) 2020 by Nayan Kumar Patel, Madhav Kumar Kedia, Chakradhar Majhi, Prafulla Kumar Bariha, Gouri Oram and Published by Siddharth Health Research and Social Welfare Society. This is an Open Access article licensed under a Creative Commons Attribution 4.0 International License https://creativecommons.org/licenses/by/4.0/ unported [CC BY 4.0] 


\section{Introduction}

Diarrhea is still a leading cause of mortality and morbidity over the world [1]. Acute diarrhea presents to primary health units are often managed with the goal for care of dehydration, prevention of the spread of infection, and empirical antibiotic in selected cases with fewer investigations done. Acute diarrhea can be attributed to viral, bacterial, and protozoan infection [2]. The peak age of presentation is although $<5$ years many episodes of acute diarrhea with hospitalization with worse dyselectrolytemia is very common in elderly $>60$ years age group [1-4]. Acute diarrhea is defined as the passage of 3 or more loose stools in 24 hours. It is an endemic condition in India with a prevalence of $7 \%[1,5]$. Electrolytes are lost in the diarrheal fluid, mainly $\mathrm{Na}+, \mathrm{K}+, \mathrm{Cl}_{-}, \mathrm{HCO}_{3}$. Also, sodium and water reabsorption in the bowel is inhibited. Due to the loss of sodium and water in diarrhea, the body tries to retain sodium under the influence of aldosterone. To maintain intracellular $\mathrm{pH}$, other cations like $\mathrm{K}+$ and $\mathrm{Mg}_{2}+$ are pushed out of the cells and lost in the urine. This aggravates hypokalemia and hypomagnesemia [5]. Inadequate and inappropriate fluid replacement and many underlying comorbidities and drugs, environmental factors contribute to dyselectrolytemia even if the dehydration is corrected. Unrecognized or poorly treated electrolyte imbalance can lead to significant morbidity and even mortality. Though studies have revealed a deficiency in serum Magnesium, Calcium, and phosphate levels in acute dehydrating diarrhea still rarely these levels are estimated as routine investigations $[3,4]$. If the loss of these electrolytes is known, a correct replacement can be begun before signs and symptoms of disturbed calcium, magnesium imbalance appears and that can hasten recovery [6].

The epidemiology of hospitalization associated with acute diarrheas in adults is not well been investigated so far, even though it imposes a major burden on the patient and health care system. Although Serum Sodium and Potassium levels are routinely done in patients of acute gastroenteritis whereas Serum Calcium and Magnesium are not routinely studied. Hence, this study was undertaken to study the changes in the level of serum calcium and magnesium in patients of acute gastroenteritis and correlating it with other electrolytes, the total number of vomiting and loose stools, duration of hospital stay.

\section{Aims and Objectives}

\section{General objective}

To study serum calcium and magnesium levels in acute gastroenteritis.

\section{Specific objectives-}

- To measure changes in serum calcium and magnesium levels in acute gastroenteritis.

- Correlating changes in levels of serum calcium and magnesium with changes in levels of serum sodium and potassium.

- Correlating changes in levels of serum calcium and magnesium with the total number of loose stools and vomiting at the time of presentation.

- Correlating levels of serum calcium and magnesium with a duration of stay at the hospital.

\section{Material and Methods}

Settings: The study was conducted in the department of General Medicine of VSS Institute of Medical Science And Research (VIMSAR), Burla, Odisha.

Duration and Study design: The study was conducted from November 2018 to December 2019. It was an Observational study

Study subjects: The study was conducted on patients admitted of acute gastroenteritis admitted to the Department of General Medicine and Infectious diseases of VIMSAR, Burla

Sample size: Random sampling was considered in the study; as per this, 100 patients were included in this research.

Inclusion criteria: Abrupt onset of 3 or more loose stools per day, Less than 14 days duration, Age greater than 14 years.

Exclusion criteria: Patient already receiving any form of calcium and magnesium therapy or any prior treatment, pregnancy and other vulnerable groups, Liver disease, Hypoalbuminemia due to any cause, cardiac ailments, severe anemia, renal insufficiency, Diabetes mellitus, Tuberculosis abdomen, acute Pancreatitis, Inflammatory bowel disease, Irritable bowel syndrome, Malignancy, etc.

Method of collection of data: By direct questioning and examination of the study group. 
Sampling procedure: All patients presenting with acute gastroenteritis and fulfilling the inclusion and exclusion criteria were included in the study. Blood was collected in a clean and dry test tube and was allowed to clot. Then it was centrifuged for 3 minutes and the clear supernatant fluid was collected for estimation. The volume of the sample $-150 \mu l$. Demographic, medical, laboratory records from the participants were collected and documented in a predesigned format. Data were analyzed using MS excel, XPSS Software, One way ANOVA. All categorical variables were described as percentages and continuous variables were expressed as mean and standard deviation. Regression analysis was done and $r$ values were obtained statistical significance was declared if $p<0.05$.

Ethical issue: The study was approved by the institutional ethics committee.

\section{Results}

In, the present study, out of 100 patients, 56\% were male and $44 \%$ were female (Fig 1). Maximum patients were of the age group 26-35(24\%) with an age range from a minimum of 17 years to maximum age of 80 years. The mean age was $42.14 \pm 16.153$ (Fig-1).

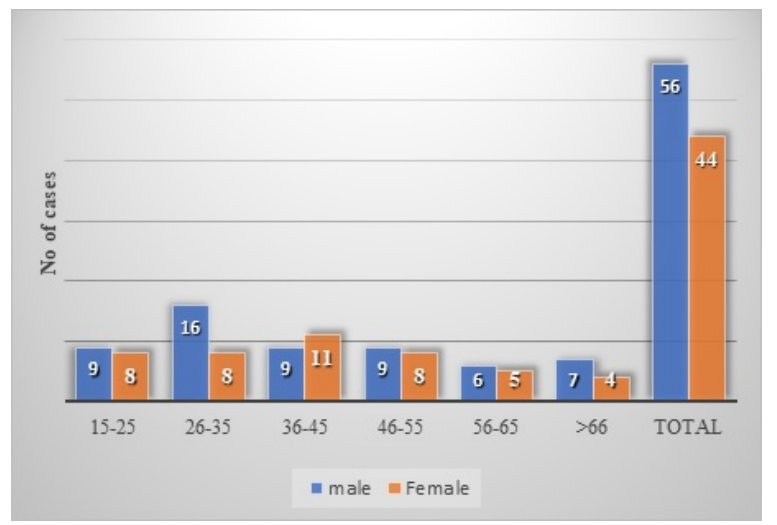

Fig-1: Age and Sex distribution of cases.

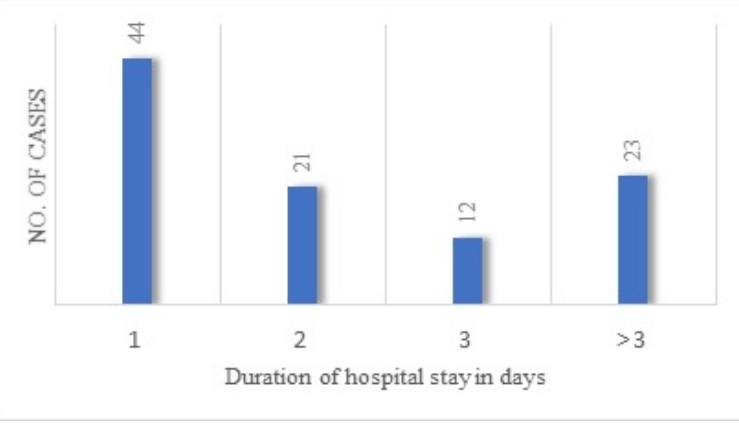

Fig-2: Categorization according to the duration of hospital stay.

The minimum duration of hospital stay was 1 day to a maximum of 6 days with a mean of 2.3 days \pm 1.494 . The majority of the patients stayed for 1 day (Fig-2).

Figure 3 depicts episodes of vomiting among participants. The majority of the cases had 1-3 episodes of vomiting. 4 patients had 9-10 episodes of vomiting during a hospital stay. Mean episodes of vomiting were $3.41 \pm 2.288$.

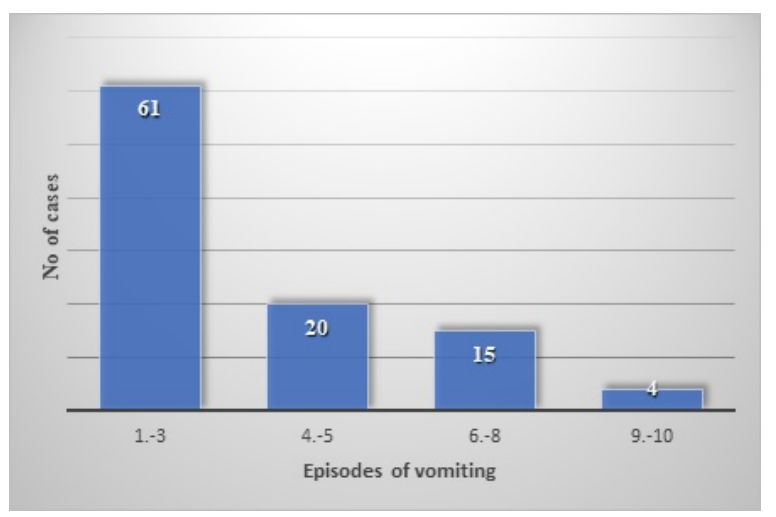

Fig-3: Categorization of patients according to total episodes of vomiting.

The total frequency of loose stools within 3-5 was $(n=3)$ and 24 patients had more than 15 episodes of loose stools. The mean frequency of stools was $12.79 \pm 4.302$ with the majority of cases (45\%) had loose stool frequency between 11 to 15 episodes (Fig-4).

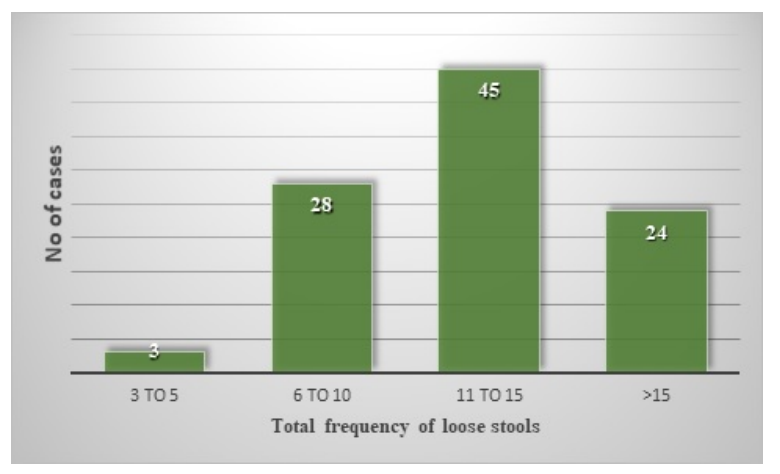

Fig-4: Categorization of patients according to total episodes of loose stools.

The minimum value of serum sodium obtained was $120 \mathrm{mmol} / \mathrm{l}$. and the maximum was $150 \mathrm{mmol} / \mathrm{l}$ with a mean of $134.723 \mathrm{mmol} / \mathrm{l}$ with a standard deviation of 0.6.6726. The majority of cases were in the range of $135.1-140 \mathrm{mmol} / \mathrm{l}(36 \%)$. 
Total cases with a value of $\leq 135 \mathrm{mmol} / \mathrm{l}$ were $48 \%$ (Fig-5). The values of serum potassium documented were a minimum of $1.5 \mathrm{mmol} / \mathrm{l}$ to a maximum of 5 $\mathrm{mmol} / \mathrm{l}$ with a mean of $3.366 \mathrm{mmol} / \mathrm{l} \pm 0.6 .6726$. The majority of cases were in the range of 2.6-3.5 $\mathrm{mmol} / \mathrm{l}(36 \%)$. Total cases with a value of serum potassium $\leq 3.5 \mathrm{mmol} / \mathrm{l}$ were $59 \%$ (Fig-6).

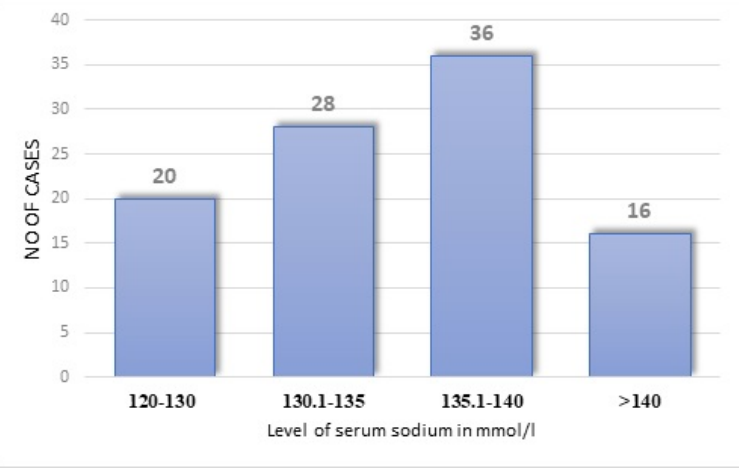

Fig-5: Categorization of cases according to serum sodium level.

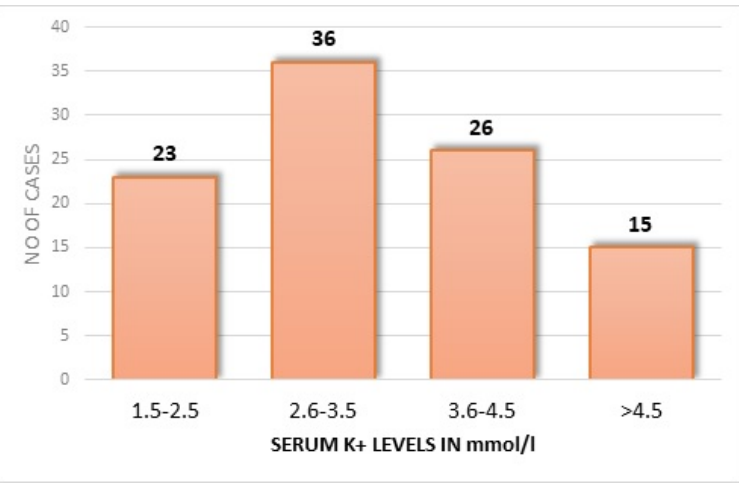

Fig-6: Categorization of cases according to serum potassium level.

The range of serum calcium obtained was 6.7 to 9.8 $\mathrm{mmol} / \mathrm{l}$ (mean $8.223 \mathrm{mmol} / \mathrm{L} \pm 0.5590$ ). The majority of cases were in the range of $8.1-8.5 \mathrm{mmol} / \mathrm{l}(57 \%)$ followed by 21 cases of serum Calcium value within 6.7-8 $\mathrm{mmol} / \mathrm{l}$ (Fig-7). About the levels of serum magnesium, the range obtained was 1.1 to 2.9 $\mathrm{mg} / \mathrm{dl}$ (mean1.710 mg/dl \pm 0.3935 ). The majority of cases were in the range of $1.7-1.9 \mathrm{mg} / \mathrm{dl}$ (35\%).
Total cases with value of serum magnesium $<1.7$ $\mathrm{mg} / \mathrm{dl}$ were $(49 \%)$ (Fig- 8 ).

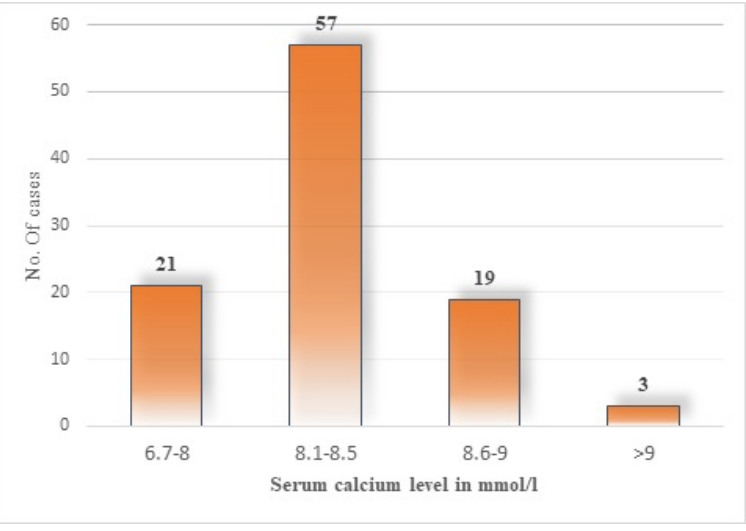

Fig-7: Categorization of cases according to serum calcium level.

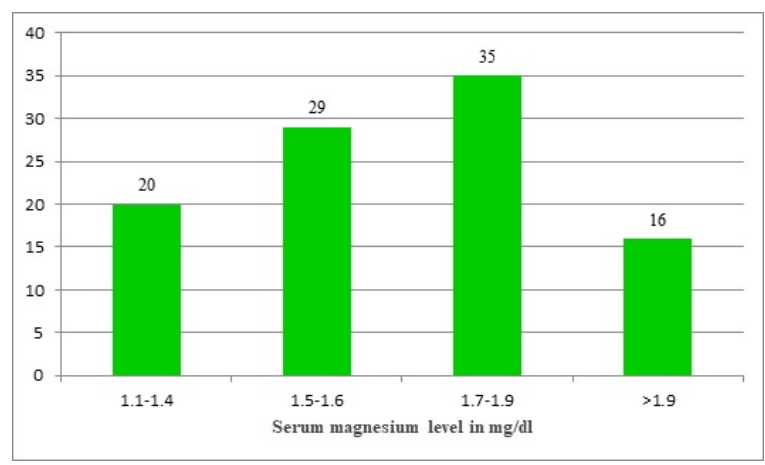

Fig-8: Categorization of cases according to serum magnesium level.

Correlation between Serum calcium and total episodes of vomiting having r-value of -0.536 with p-value $<0.05$ which is significant. Correlation between Serum calcium and total episodes of stool having $r$ value -0.88 with $p<0.05$ which is significant and the correlation between Serum calcium and serum sodium having $r$ value 0.374 with $p$-value $<0.05$ which is significant. Correlation between Serum calcium and serum potassium having $r$ value 0.729 with $p<0.05$ and Correlation between Serum calcium and duration of hospital stay having $r$ value -0.770 with $p<0.05$ which are significant (Table-1).

\section{Table-1: Correlations between Ca2+ and other variables.}

\begin{tabular}{|c|c|c|c|c|c|c|c|}
\hline & & $\mathrm{Ca}$ & Vf & Sf & $\mathrm{Na}+$ & $\mathrm{K}+$ & DOHS \\
\hline $\mathrm{Ca} 2+$ & $\begin{array}{l}\text { Pearson Correlation } \\
\text { Sig. (2-tailed) } \\
\mathrm{N}\end{array}$ & $\left.\right|_{100} ^{1}$ & $\begin{array}{l}-0.536 * * \\
.000 \\
100\end{array}$ & $\begin{array}{l}-.880 * * \\
.000 \\
100\end{array}$ & $\begin{array}{l}.374 * * \\
.000 \\
100\end{array}$ & $\begin{array}{l}.729 * * \\
.000 \\
100\end{array}$ & $\begin{array}{l}-.770 * * \\
.000 \\
100\end{array}$ \\
\hline Vf & $\begin{array}{l}\text { Pearson Correlation } \\
\text { Sig. (2-tailed) } \\
\mathrm{N}\end{array}$ & $\begin{array}{l}-.536 * * \\
.000 \\
100\end{array}$ & 1 & & & & \\
\hline
\end{tabular}




\begin{tabular}{|c|c|c|c|c|c|c|}
\hline Sf & $\begin{array}{l}\text { Pearson Correlation } \\
\text { Sig. (2-tailed) } \\
\text { N }\end{array}$ & $\begin{array}{l}-.880 * * \\
.000 \\
100\end{array}$ & $\left.\right|_{100} ^{1}$ & & & \\
\hline $\mathrm{Na}+$ & $\begin{array}{l}\text { Pearson Correlation } \\
\text { Sig. (2-tailed) } \\
\text { N }\end{array}$ & $\begin{array}{l}.374 * * \\
.000 \\
100\end{array}$ & & $\left.\right|_{100} ^{1}$ & & \\
\hline $\mathrm{K}+$ & $\begin{array}{l}\text { Pearson Correlation } \\
\text { Sig. (2-tailed) } \\
\text { N }\end{array}$ & $\begin{array}{l}.729 * * \\
.000 \\
100\end{array}$ & & & $\begin{array}{l}1 \\
100\end{array}$ & \\
\hline DOHS & & $\begin{array}{l}-.770 * * \\
.000 \\
100\end{array}$ & & & & $\mid \begin{array}{l}1 \\
100\end{array}$ \\
\hline
\end{tabular}

$* *$ Correlation is highly significant at .01

DOHS-Days of hospital stay/Sf-stool frequency/ Vfvomiting frequency

Correlation between magnesium and total episodes of vomiting having $r$ value $(-0.475)$ with $p$-value $<0.05$. Correlation between magnesium and total episodes of vomiting having $r$ value -0.498 with $p$ value $<0.05$.
Correlation between magnesium and serum sodium having $r$ value 0.301 with $p$-value $<0.05$. Correlation between magnesium and serum potassium having $r$ value 0.801 with $p$-value $<0.05$. Correlation between magnesium and duration of hospital stay having $r$ value -0.699 with $p$-value $<0.05$ which is significant (Table-2).

Table-2: Correlations between $\mathrm{Mg2+}$ and other variables.

\begin{tabular}{|c|c|c|c|c|c|c|c|}
\hline & & $\mathrm{Mg} 2+$ & $V f$ & Sf & $\mathrm{Na}+$ & $\mathrm{K}+$ & DOHS \\
\hline Mg2+ & $\begin{array}{l}\text { Pearson Correlation } \\
\text { Sig. (2-tailed) } \\
\mathrm{N}\end{array}$ & $\begin{array}{l}1 \\
100\end{array}$ & $\begin{array}{l}-.475^{* *} \\
.000 \\
100\end{array}$ & $\begin{array}{l}-.498 * * \\
.000 \\
100\end{array}$ & $\begin{array}{l}.301^{* *} \\
.002 \\
100\end{array}$ & $\begin{array}{l}.801^{* *} \\
.000 \\
100\end{array}$ & $\begin{array}{l}-.699 * * \\
.000 \\
100\end{array}$ \\
\hline vf & $\begin{array}{l}\text { Pearson Correlation } \\
\text { Sig. (2-tailed) } \\
\mathrm{N}\end{array}$ & $\begin{array}{l}-.475^{* *} \\
.000 \\
100\end{array}$ & $\mid \begin{array}{l}1 \\
100\end{array}$ & & & & \\
\hline Sf & $\begin{array}{l}\text { Pearson Correlation } \\
\text { Sig. (2-tailed) } \\
\mathrm{N}\end{array}$ & $\begin{array}{l}-.498 * * \\
.000 \\
100\end{array}$ & & $\begin{array}{l}1 \\
100\end{array}$ & & & \\
\hline $\mathrm{Na}+$ & $\begin{array}{l}\text { Pearson Correlation } \\
\text { Sig. (2-tailed) } \\
\mathrm{N}\end{array}$ & $\begin{array}{l}.301^{* *} \\
.002 \\
100 \\
\end{array}$ & & & 100 & & \\
\hline $\mathrm{K}+$ & $\begin{array}{l}\text { Pearson Correlation } \\
\text { Sig. (2-tailed) } \\
\mathrm{N}\end{array}$ & $\begin{array}{l}.801 * * \\
.000 \\
100\end{array}$ & & & & $\mid \begin{array}{l}1 \\
100\end{array}$ & \\
\hline DOHS & & $\begin{array}{l}-.699 * * \\
.000 \\
100\end{array}$ & & & & & $\mid \begin{array}{l}1 \\
100\end{array}$ \\
\hline
\end{tabular}

$* *$ Correlation is highly significant at .01 DOHS-Days of hospital stay/ Sf-stool frequency/ Vfvomiting frequency

\section{Discussion}

In this study, the peak incidence of acute
Gastroenteritis was in the age group 26-35years $(24 \%)$. Only $11 \%$ of cases were found in the older age group ( $>65$ years). Males were more $56 \%$ than females. This finding is similar to the finding of Anjali et al [8] The minimum age was 17 years and the maximum age was 80 years with a mean age of $42.14 \pm 16.15$ years. 
In a study by Patel et al [9], there were 71 males and 29 females in cases of acute diarrhea. Maximum numbers of cases were between the ages of 21-50 years. In a study by Rajoor UG et al [10], out of 100 patients of acute diarrhea studied, 57 were males and 43 were females. The age of patients varied from $18-90$ years. Maximum incidence $(60 \%)$ was seen in the age group of 21-50 years. In the study by $\mathrm{KC} \mathrm{M}$ et al [11], out of sixty patients, 38 (63.3\%) were male and 22 (36.67\%) were female. The finding of the above studies supports the observations of the current study.

Hypocalcemia was seen in $97 \%$ (Mean of $8.22 \pm 0.56)$ of the study population. The majority (57\%) had serum calcium lying between 8.1 to 8.5 $\mathrm{mmol} / \mathrm{L}$ followed by 6.7 to $8 \mathrm{mmol} / \mathrm{L}(21 \%)$ and 8.5 to $9 \mathrm{mmol} / \mathrm{L}$ (19\%) which was similar to the finding of Anjali et al [8] whereas hypocalcemia was present in $94 \%$ of patients in the study conducted by Bhikha et al. [7]. This difference is because of the altered cut off value for defining hypocalcemia $(<8.5 \mathrm{mg} / \mathrm{dl})$ in the study.

In the present study, hypomagnesemia (less than $1.7 \mathrm{mg} / \mathrm{dl}$ ) was seen in $49 \%$ of the study population. The majority of the population (29\%) had serum magnesium lying between 1.5 to 1.6 $\mathrm{mg} / \mathrm{dl}$ followed by 1.1 to $1.4 \mathrm{mg} / \mathrm{dl}$ (20\%). The minimum serum magnesium level was $1.1 \mathrm{mg} / \mathrm{dl}$ and the maximum was $2.9 \mathrm{mg} / \mathrm{dl}$ with a mean of $1.71 \pm 0.39 \mathrm{mg} / \mathrm{dl}$. The findings are comparable to Patel et al [9] where 55\% had hypomagnesemia on admission and $6 \%$ cases had severe hypomagnesemia. Hyponatremia was seen in $48 \%$ of the study population. The majority of the population (28\%) had hyponatremia with serum sodium lying between 130.1 to $135 \mathrm{mmol} / \mathrm{L}$ followed by 120 to $130 \mathrm{mmol} / \mathrm{L}(20 \%)$ compared to $35 \%$ of the study population had hyponatremia in the study of Anjali et al [8] and lower than the study by Patel et al [9] (80\%).

In the present study, hypokalaemia was seen in $59 \%$ of the study population. The minimum serum potassium level was $1.5 \mathrm{mmol} / \mathrm{L}$ and the maximum was $5.1 \mathrm{mmol} / \mathrm{L}$ with a mean of $3.37 \pm 0.98$. $\mathrm{mmol} / \mathrm{L}$. The majority of the population (36\%) had hypokalaemia with serum potassium lying between 2.6 to $3.5 \mathrm{mmol} / \mathrm{L}$ followed by 1.5 to $2.5 \mathrm{mmol} / \mathrm{L}$ (23\%) compared to Patel et al [9] were $39 \%$ cases had hypokalaemia on admission and $22 \%$ cases had severe hypokalaemia higher than $23 \%$ of study by Anjali et al [8].
The correlation of serum calcium levels with total episodes of vomiting has a Pearson coefficient, $r$ value -0.536 with a $\mathrm{p}$-value $<0.05$. The serum calcium level is inversely proportional to total episodes of vomiting; which was found to be statistically significant. The correlation of serum calcium levels with total episodes of stools has a Pearson coefficient, $r$ value -0.880 with a $p$-value < 0.05 , the serum calcium level is inversely proportional to total episodes of stools; which was also found to be statistically significant. The changes in serum calcium level have a stronger association with total episodes of stools than that of vomiting.

The correlation of serum calcium levels with serum sodium level has a Pearson coefficient, $r$ value 0.374 with a $p$-value $<0.05$. The serum calcium level is directly proportional to serum sodium level; which was found to be statistically significant. The correlation of serum calcium levels with serum potassium level has a Pearson coefficient, $r$ value 0.729 with a $p$-value $<0.05$. The serum calcium level is directly proportional to serum potassium level; which was found to be statistically significant. The changes in serum calcium level have a stronger association with serum potassium level than serum sodium level.

In this study, the correlation of serum calcium levels with the duration of hospital stay has a Pearson coefficient, $r$ value -0.770 with a $p$-value $<0.05$. The serum calcium level is inversely proportional to the duration of hospital stay; which was found to be statistically significant. The correlation of serum magnesium levels with total episodes of vomiting has a Pearson coefficient, $r$ value -0.475 with a $p$ value $<0.05$. The serum magnesium level is inversely proportional to total episodes of vomiting; which was found to be statistically significant. The correlation of serum magnesium levels with total episodes of stools has a Pearson coefficient, $r$ value - 0.498 with a $p$-value $<0.05$, the serum magnesium level is inversely proportional to total episodes of stools; which was found to be statistically significant. The changes in serum magnesium level have a stronger association with total episodes of stools than that of vomiting.

In the present study, the correlation of serum magnesium levels with serum sodium level has a Pearson coefficient, $r$ value 0.301 with a $p$-value < 0.05 . The serum magnesium level is directly proportional to serum sodium level; which was found to be statistically significant. 
The correlation of serum magnesium levels with serum potassium level has a Pearson coefficient, $r$ value 0.801 with a $p$-value $<0.05$, the serum magnesium level is directly proportional to serum potassium level; which was found to be statistically significant. The changes in serum magnesium level have a stronger association with serum potassium level than serum sodium levels.

The correlation of serum magnesium levels with a duration of hospital stay has Pearson coefficient, $r$ value -0.699 with a $p$-value $<0.05$. The serum magnesium level is inversely proportional to the duration of hospital stay; which was found to be statistically significant. The correlations described above have never been earlier studied in the adult population in patients of acute gastroenteritis.

\section{Limitations}

The sample size was only 100 . So, it may not have been represented by the target population. Electrolyte estimation was done only on admission.

A comparative data on admission versus on discharge would throw light on how the treatment influences the electrolyte imbalance it would also point out the limitations of conventional treatment protocols.

Secondly, stool levels of $\mathrm{Mg} 2+, \mathrm{K}+, \mathrm{Ca}+$, and urinary $\mathrm{Mg} 2+, \mathrm{K}+$ levels could not be measured to document the loss of $\mathrm{Mg} \mathrm{2}+$ and $\mathrm{Ca} 2+$ in stool and $\mathrm{Mg} 2+$ and $\mathrm{K}+$ loss in urine due to non-availability of these investigations at our set up.

\section{Conclusion}

In the present study, hypocalcemia (97\%), hypokalemia (59\%), hypomagnesemia (49\%), and hyponatremia $(48 \%)$ were reported. Therefore, serum electrolytes such as calcium, magnesium should also be investigated along with routine serum sodium and potassium. Early detection and prompt correction of electrolytes will be beneficial as it will decrease the duration of hospital stay, morbidity, the mortality of patients and will decrease the burden on the health system of the country.

\section{What does the study add to the existing knowledge?}

Also, adequate measures should be taken for the prevention and control of acute gastroenteritis.
Still large multicentric study with larger populations, avoiding limitations will ensure stronger evidence and strong recommendations concerning the management of acute diarrhea with dehydration and dyselectrolytenemia.

\section{Author's contribution}

Dr. Nayan Kumar Patel: Helped in data collection and analysis and preparation of the manuscript.

Dr. Madhav Kumar Kedia: -Data collection and preparation of the manuscript.

Dr. Chakradhar Majhi: - Guided data collection and preparation of the manuscript.

Dr. Prafulla Kumar Bariha: Guided to conduct this study and preparation of the manuscript.

Dr. Gouri Oram: Preparation of manuscript, critical analysis.

\section{Acknowledgements}

The authors would like to thank the patients for their adherence and kind cooperation in this study and the staff and technicians of the central laboratory for performing the different tests in the study.

\section{Reference}

01. Park K. Acute diarrheal disease. Park's Textbook of Preventive and Social Medicine, 21st Ed. 200210.

[Crossref]

02. Gangarosa RE, Glass RI, Lew JF, Boring JR. Hospitalizations involving gastroenteritis in the United States, 1985- the special burden of the disease among the elderly. Am J Epidemiol. $1992 ; 135(3) 281-290$.

doi: 10.1093/oxfordjournals.aje.a116282 [Crossref]

03. Fischer-Walker CL, Black RE. Diarrhoea morbidity and mortality in older children, adolescents, and adults. Epidemiol Infect. 2010;138(9)1215-1226.

doi: $10.1017 / \mathrm{S} 0950268810000592$ [Crossref]

04. Moe Allan E. Electrolyte Balance in Gastrointestinal Disease. Calif Med. $1955 ; 83(5) 339-342$.

[Crossref] 
05. Bringhurst FR. Bone and mineral metabolism in health and disease. Harrison's Principles of Internal Med. 2008;2365-2377.

[Crossref]

06. Whang $R$, Oei TO, Aikawa JK, Watanabe A, Vannatta J, Fryer A, et al. Predictors of clinical hypomagnesemia, hypokalemia, hypophosphatemia, hyponatremia and hypocalcaemia. Arch Intern Med. 1984;144(9)1794-1796.

[Crossref]

07. Devrajani BR, Shah SZ, Shaikh S, Shaikh S, Essa S. Hypocalcemia in acute gastroenteritis (a case control study at the department of internal medicine). World App Sci J. 2009;7(6)777-780. [Crossref]

08. Gate AK, Roy AK, Navae S. Serum calcium, magnesium and potassium in acute diarrhoea patients coming to pravara rural hospital. Int J Clin Biomed Res. 2018;4(2)7-11.

doi: $10.5455 /$ ijcbr.2018.42.02 [Crossref]
09. Purohit J, Patel N, Bharodiya R, Srivastav V. Study of Serum Magnesium Level in Acute Diarrhea. IOSR J Dent Med Sci. 2017;16(4)7680.

doi: $10.9790 / 0853-1604087680$ [Crossref]

10. Rajoor UG, Sindhur JC, Lakshmana Kumar YC. Etiological spectrum and complications of acute diarrhoeal diseases in adults. IJRRMS. 2012;2(2)9-12.

[Crossref]

11. KC M, Gurubacharya DL, Lohani R, Rauniyar A. Serum Urea, Creatinine and Electrolyte Status in Patients Presenting with Acute Gastroenteritis. JNMA J Nepal Med Assoc. 2006;45(163)291294.

[Crossref] 